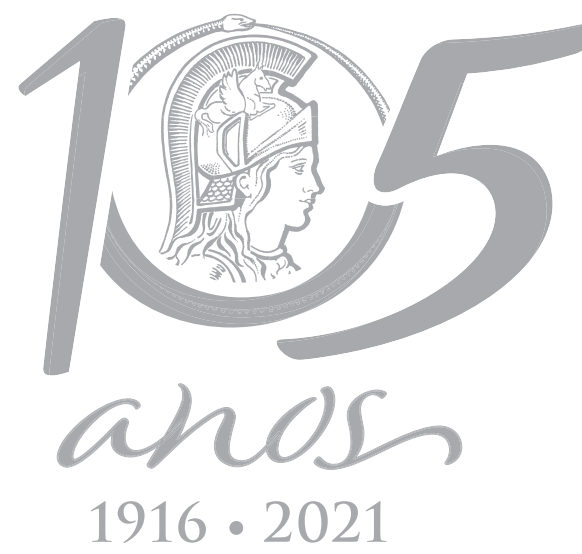

\title{
Purification and characterization of a protease from Aspergillus sydowii URM5774: Coffee ground residue for protease production by solid state fermentation
}

\author{
FELYPE T.B. ROCHA, ROMERO M.P. BRANDÃO-COSTA, ANNA GABRIELLY D. \\ NEVES, KETHYLEN B.B. CARDOSO, THIAGO P. NASCIMENTO, WENDELL W.C. \\ ALBUQUERQUE \& ANA LÚCIA F. PORTO
}

\begin{abstract}
Solid state fermentation is a promising technology largely used in biotechnology process and is a suitable strategy for producing low-cost enzymatic products. At the present study, a novel enzyme obtained through solid state fermentation using Aspergillus sydowii was herein purified and characterized. The fermentations used coffee ground residue as substrate and the crude enzyme was submitted through further purification steps of: acetonic precipitation, DEAE-Sephadex and Superdex G-75 column. Both crude and purified enzymes were submitted to biochemical characterization of their thermostability, optimal temperature and $\mathrm{pH}$, effects of inhibitors and metal ions. A purified protease was obtained with yield of 5.9-fold and 53\% recovery, with maximal proteolytic activity of $352.0 \mathrm{U} / \mathrm{mL}$. SDS-PAGE revealed a band of protein at $47.0 \mathrm{kDa}$. The enzyme activity was abolished in the presence of phenyl-methyl sulfonyl fluoride and partially inhibited against Triton $\mathrm{X}-100$ (78.0\%). The optimal activity was found in $\mathrm{pH} 8.0$ at $45^{\circ} \mathrm{C}$ of temperature. Besides, the enzyme showed stability between $35^{\circ} \mathrm{C}$ and $50^{\circ} \mathrm{C}$. It was possible to determine appropriate conditions to the obtainment of thermostable proteases with biotechnological interest associated with a method that concomitantly shows excellent production levels and recovery waste raw material in a very profitable process.
\end{abstract}

Key words: Aspergillus sydowii, biotechnology, proteases, solid state fermentation, waste coffee residue.

\section{INTRODUCTION}

Agricultural waste recovery associated with the development of techniques of conversion of raw material into economically useful products makes research of bioconversion by microorganisms increasingly relevant. Production of proteases using solid substrates through fermentative processes is pointed out in the present study as a low-cost alternative for waste recovery (Novelli et al. 2016, Albuquerque et al. 2020).

Proteases hydrolyze peptide bonds and provide essential modifications in proteins which are involved in the process of digestion, activation of enzymes, blood clotting and membrane transport. They have a variety of functions and represent approximately $60 \%$ of the enzyme world market, being often used in detergent, leather, pharmaceutical and food 
industries (Castro et al. 2014, Albuquerque et al. 2020).

Processes for obtaining proteases derived from plants are slower than others, due to plant senescence. This period is a natural developmental process, but it is also closely linked to abiotic and biotic stresses. This physiological set of events can be modulated by endogenous and exogenous factors such as plant growth regulators, so the protease production aiming to industrial field should be difficult. At the same time, proteases from animal origin (for example pepsin, chymosin and trypsin) need to be prepared in larger scale and are dependent on the cattle for slaughter, what hinders its use. Microbial proteases, on the other hand, are considered commercial profitable enzymes, because their biochemical diversity, rapid growth, and fast and safe production (Mansor et al. 2019), presenting therefore higher economic potential.

Aspergillus is in the order Eurotiales also comprising the genera Penicillium, which are known to have a potential for producing various metabolites such as antibiotics, organic acids, medicines or enzymes, milk-clotting enzymes and extracellular proteases (Silva et al. 2018). Filamentous fungi are widely applied for production of enzymes as amylases, lipases, proteases and pectinases (Sethi et al. 2016), and the processes are advantageous for their low cost of materials, high production and recovery, since they are obtained from the extracellular medium (Vishwanatha et al. 2009, Souza et al. 2015). The genus Aspergillus is the most common filamentous fungi used in industry.

The solid-state fermentation (SSF) provides some advantages over the submerged (SMF) such as: the use of agricultural residues as substrates (wheat bran, soybean, rice, bagasse, and nuts); requires low amount of water; produces more concentrated metabolites; obtained by stationary process (causing no energy costs); and in most cases the enzyme yield is higher (Zenebon et al. 2008).

With high production of the world coffee industry, a lot of waste is generated, and it is estimated that 9.9 million solid waste are produced annually worldwide (Tang et al. 2020) which draws attention to a high waste of raw materials and environmental damage.

Disposal of residues in agro-industrial processes represents a large financial disadvantage that could be prevented from reuse of raw material for obtaining biotechnological enzymes (Albuquerque et al. 2020). The present work aims to follow the multistep process (production, purification, characterization, and application) for converting coffee ground residues into a purified protease through solid state fermentation by Aspergillus sydowii.

\section{MATERIALS AND METHODS}

\section{Chemicals}

Azocasein, DEAE-sephadex G50, trichloroacetic acid, ammonium sulfate, $\beta$-mercaptoethanol, Tris (hydroxymethyl) aminomethane, glycine, Phenylmethylsulphonyl fluoride (PMSF) and protein markers of molecular weights were purchased from Sigma Chemicals (St Louis, USA). Ammonium persulfate, $N, N, N^{\prime}, N^{\prime}$-tetramethyl ethylene diamine (TEMED), acrylamide, sodium dodecyl sulfate (SDS) and Coomassie Brilliant Blue R-250 were obtained from BioRad Laboratories (Hercules, CA, USA). All other reagents were of analytical grade.

\section{Microorganism}

The microorganism used was the Aspergillus sydowii URM5774, isolated from the coffee grounds and duly identified by the URM Culture Collection of the Federal University of Pernambuco. The cultures were stocked in the 
medium Potato Dextrose Agar (PDA) at room temperature $\left( \pm 26^{\circ} \mathrm{C}\right)$.

\section{Inoculum preparation}

The culture was maintained in Potato Dextrose Agar (PDA) at $30^{\circ} \mathrm{C}$ for 7 days. Then, the spores were suspended in a nutrient solution previously sterilized that comprised the culture medium Potato Dextrose Agar (PDA) in $0.15 \mathrm{M} \mathrm{NaCl}$ solution ( $5 \mathrm{~mL}$ ) according to Nascimento et al. (2017). The number of spores was standardized in a Neubauer chamber (Laboroptik, Lacing, United Kingdom) to obtain the final concentration of $10^{7}$ spores/mL.

\section{Solid state fermentation (SSF)}

Solid state fermentation (SSF) was used as carbon and nitrogen source from coffee ground residues. The coffee residues were obtained from the university restaurant in the Universidade Federal Rural de Pernambuco (UFRPE), Recife, Brazil, and kept in oven for a period of $72 \mathrm{~h}$ at $50^{\circ} \mathrm{C}$, to ensure complete drying of the coffee to obtain a constant weight. The fermentations were carried out with $4 \mathrm{~g}$ of coffee residue, during $72 \mathrm{~h}$, at $30^{\circ} \mathrm{C}$, according to Zenebon et al. (2008) and deposited in a germination chamber (BOD) until the end of the process. The compositions of the solid-state fermentation consisted of coffee residue ( $4.0 \mathrm{~g}$ ) as a substrate (moisture content of 60\%) which were sterilized by autoclaving at $121^{\circ} \mathrm{C}$, for $20 \mathrm{~min}$, inoculated with the suspension of $A$. sydowii spores (final concentration $10^{7}$ spores $/ \mathrm{mL}$ ), and incubated at $30^{\circ} \mathrm{C}$ for $72 \mathrm{~h}$. After incubation, $7.5 \mathrm{~mL}$ of 100 mM Tris- $\mathrm{HCl}$ buffer $\mathrm{pH} 8.0$ were added per $\mathrm{g}$ of substrate and the flasks were placed in an orbital shaker at $150 \mathrm{rpm}$ for $120 \mathrm{~min}$ at $25^{\circ} \mathrm{C} \pm 2$.

\section{Enzyme extraction}

For the protease extraction, $30.0 \mathrm{~mL}$ (0.1 M Tris$\mathrm{HCl}$ buffer $\mathrm{pH}$ 8.0) were added to solid state fermentation $(7.5 \mathrm{~mL} / \mathrm{g}$ of substrate), followed by orbital agitation (2h), and after to filtration with filter paper in using vacuum pump. The crude extract was centrifuged at 12,000 xg for $30 \mathrm{~min}$ at $4^{\circ} \mathrm{C}$, and the supernatant was used as crude enzyme to the subsequent purification steps (Nascimento et al. 2017).

\section{Determination of protease activity}

Protease activity was measured as described by Ginther (1979). Assay mixtures of $1.0 \mathrm{~mL}$ containing $0.2 \mathrm{M}$ Tris- $\mathrm{HCl}, \mathrm{pH} 7.2,1 \mathrm{mM} \mathrm{CaCl}$, $1 \%$ Azocasein and $150 \mu \mathrm{L}$ of enzymatic purified, were incubated at $28^{\circ} \mathrm{C}$ for $1 \mathrm{~h}$. After stopping the reaction by adding $1.0 \mathrm{~mL}$ of $10 \%$ trichloroacetic acid, samples were centrifuged at 3,000 g for $15 \mathrm{~min}$, and $0.8 \mathrm{~mL}$ of the supernatant was transferred into a second tube containing $0.2 \mathrm{~mL}$ of 1.8 M NaOH. Finally, samples were blended in a vortex mixer, and the absorbance was measured at $\lambda 420 \mathrm{~nm}$. One unit of protease activity was defined as the amount of enzyme responsible for a 0.1 increase per hour in the absorbance.

\section{Protein measurements}

Protein concentration was determined according to the method of Smith et al. (1985). Bovine serum albumin was used as standard for protein determination and a standard curve was done using a range at 40 to $500 \mathrm{ug} / \mathrm{mL}$.

\section{Acetonic precipitation}

The partial purification process was performed using the method of precipitation with acetone at $70 \%$ and centrifuged at $16.800 \times g$ during 10 min (Nascimento et al. 2017). Then the precipitate was separated from the supernatant and resuspended in Tris- $\mathrm{HCl}$ buffer $\mathrm{pH} 8.0$ to obtain the acetonic fraction. 


\section{DEAE-Sephadex Chromatography}

The acetonic fraction was submitted through a DEAE-Sephadex G-50 column, equilibrated with $0.1 \mathrm{M}$ Tris- $\mathrm{HCl}$ buffer, $\mathrm{pH}$ 8.0. In this case, the samples were eluted with different concentrations of $\mathrm{NaCl}$ solutions $(0.3 \mathrm{M}, 0.6 \mathrm{M}$, and $1 \mathrm{M}$ ), diluted in the same buffer. Fractions of $1.0 \mathrm{~mL}$ were collected at a flow of $1 \mathrm{~mL} / \mathrm{min}$ after the addition of elution buffer, the process was monitored at $280 \mathrm{~nm}$ in spectrophotometer. The fractions with protease activity was pooled and the enzyme solution concentrated for further step in Gel Filtration Chromatography. All the steps were done according to Nascimento et al. (2017).

\section{Gel Filtration Chromatography}

An aliquot $(1.0 \mathrm{~mL})$ of the sample obtained from DEAE which presented activity was submitted to Gel filtration. The analysis was performed using Tris- $\mathrm{HCl}$ buffer $0.1 \mathrm{M}(\mathrm{pH} \mathrm{8)}$ ) added of $0.15 \mathrm{M} \mathrm{NaCl}$ in an ÄKTA Avant 25 System (GE Healthcare, Uppsala, Sweden) on Superdex G 75 (HR10/300GL), PC 3.2/30 column, as described in the manufacturer's instructions. The absorbance of the samples was evaluated at $215 \mathrm{~nm}$ and 280 $\mathrm{nm}$. The column was calibrated using a mixture of molecular weight markers (1 $\mathrm{mg} / \mathrm{mL}$ each): bovine serum albumin, carbonic anhydrase and albumin from chicken egg and a trypsin inhibitor. All the steps were done according to Nascimento et al. (2017).

\section{Electrophoresis and protein staining}

The SDS-PAGE method was performed according to Laemmli (1970) with a 10\% resolving gel and a $5 \%$ stacking gel, under non-reducing conditions. The gels were stained with Coomassie Brilliant Blue and kept incubated for $15 \mathrm{~h}$ at room temperature under gentle shaking.

\section{Biochemical characterization}

\section{Effect of inhibitors and metal ions on proteinase activity}

To evaluate the effect of inhibitors and metal ions on the protease activity, the purified enzyme $(150 \mu \mathrm{l})$ was lyophilized, then resuspended with different solutions $(150 \mu \mathrm{L})$ containing: Phenylmethyl-sulfonyl-Fluor (PMSF); ethylenediamine tetra acetic acid (EDTA); $\beta$-mercaptoethanol and ions $\mathrm{Fe}^{+2}, \mathrm{Mg}^{+2}, \mathrm{Ca}^{+2}, \mathrm{Mn}^{+2}$ and $\mathrm{CO}^{+2}$ at $0.2 \mathrm{M}$, during $30 \mathrm{~min}$. All the steps were done according to Nascimento et al. (2017).

\section{Effect of pH (optimum and stability) and temperature (optimum and stability) on purified protease activity.}

The purified enzyme obtained from Gel filtration chromatography was subjected to different temperatures varying from $5^{\circ} \mathrm{C}$, from $20^{\circ} \mathrm{C}$ to $100^{\circ} \mathrm{C}$ for 60 minutes to evaluate the thermostability and then performing the measurement of activities. All the steps were done according to Nascimento et al. (2017). The optimum temperature was assessment by incubation of enzyme and substrate in temperatures varying from $5^{\circ} \mathrm{C}$, from $20^{\circ} \mathrm{C}$ to $100^{\circ} \mathrm{C}$, where the reaction presenting and described in 2.6 topic was done.

The $\mathrm{pH}$ stability was determined by resuspending the purified enzyme, previously lyophilized, in different buffers with different $\mathrm{pH}$ : acetate buffer $0.2 \mathrm{M}$ at pH 5.0 and 6.0 and 0.2 M Tris- $\mathrm{HCl}$ buffer at $\mathrm{pH} 7.0,8.0$ and 9.0. After, the samples were subjected to protease reaction described in topic 2.6. All the steps were done according to Nascimento et al. (2017). The optimum pH was achieved changing the $\mathrm{pH}$ buffer solutions described in topic 2.6. The concentration of enzyme and substrate was maintained. The optimum $\mathrm{pH}$ was determined 
to be in the range of 4.0-12.0 using different buffers (Sodium citrate, $\mathrm{NaOH}$ and Tris- $\mathrm{HCl}$ ) at $50 \mathrm{mM}$ concentration. All the steps were done in triplicate according to Nascimento et al. (2017).

\section{Potential hydrolysis of azocasein}

To evaluate the potential hydrolysis of azocasein substrate, after FPLC, an aliquot of enzyme plus substrate solution was pooled at different temperature and lyophilized, and later resuspended with $1.0 \mathrm{~mL}$ of $0.1 \%$ trifluoracetic acid (TFA) solution, and an aliquot $(50 \mu \mathrm{L})$ was submitted to high performance liquid chromatography (HPLC) and eluted using a 0 - 90\% acetonitrile. The samples were applied sequentially to reverse - phase high performance liquid chromatography (RP - HPLC) coupled to an electro spray ionization mass spectrometer (ESI - MS) using an LC/ MS - 2020 EV (Prominence Shimadzu Corporation, Tokyo, Japan). The chromatography process was assessed on a C18 column (Ultra sphere, $5 \mu \mathrm{m}, 4.6 \times 250 \mathrm{~mm}$ ) and monitored using a UV-detector (Shimadzu UV vis SPD - 20AV) at $220-365 \mathrm{~nm}$.

\section{Effect of inhibitors on protease activity}

To evaluate the effect of inhibitors on enzyme activity, the purified enzyme was exposed to the following protease inhibitors: PMSF (10 mM), $\beta$-mercaptoethanol (10 mM), ethylenediaminetetraacetic acid (EDTA) (10 mM), Pepstatin A (1mM) and Iodoacetic acid (10 mM). Each inhibitor was dissolved according to the Sigma protocol and incubated for $30 \mathrm{~min}$ at $25^{\circ} \mathrm{C}$ with the enzyme. The enzyme activity without inhibitor was considered as control (100\%).

\section{Statistical analysis}

All data were analysed statistically using the General Linear Models procedure of the Statistix 8.1 software package (Analytical Software, St Paul,
MN, USA) and presented as the mean \pm standard error (SE). All assays were done in triplicate.

\section{RESULTS AND DISCUSSION}

\section{Enzyme production}

Factors such as humidity, temperature, extraction type and time of incubation were studied aiming to optimize the production of protease. A. sydowii was able to produce a protease (crude extract) with high activity (specific activity of $8.59 \mathrm{U} / \mathrm{mL}$ and a content proteolytic $89.8 \mathrm{mg} /$ $\mathrm{mL}$ ). The humidity, temperature and the time of incubation showed the best production at $60 \%$, $30^{\circ} \mathrm{C}$ and 5 days, respectively, in comparison with other tested conditions. The data also demonstrate that the coffee ground is a valuable substrate for protease production, since $4.0 \mathrm{~g}$ of coffee residue was enough to produce 1.16 $\mathrm{mg} / \mathrm{mL}$ of protease with $256 \mathrm{U} / \mathrm{mL}$ of activity. Proteases are proteolytic enzymes that catalyze the cleavage of peptide bonds in proteins. These enzymes form an exceptionally large and diverse group of complex enzymes which have different properties such as a substrate, an active site and a catalytic mechanism, optimal pH, and a profile of stable temperatures (Silva et al. 2018).

\section{Enzyme purification and electrophoresis (SDS- PAGE)}

Partial purification by acetone precipitation concentrated and consequently increased the protease specific activity (see Table I). In this step, the enzyme was recovered by $93 \%$ with 2.11-fold purification. Novelli et al. (2016) using wheat bran and soybean meal as substrate for fermentations by Aspergillus did not exceed the value of $40 \mathrm{U} / \mathrm{mL}$ of protease activity with this pre-purification step.

The subsequent two chromatographic steps (anion-exchange and gel filtration chromatography) improved the enzyme purity, 
Table I. Purification steps of protease from Aspergillus sydowii.

\begin{tabular}{|c|c|c|c|c|c|}
\hline Purification step & $\begin{array}{c}\text { Total activity } \\
\text { (U) }\end{array}$ & $\begin{array}{c}\text { Total protein } \\
\text { (mg) }\end{array}$ & $\begin{array}{c}\text { Specific activity (U/ } \\
\mathbf{m g})\end{array}$ & $\begin{array}{c}\text { Purification } \\
\text { (Fold) }\end{array}$ & $\begin{array}{c}\text { Recovery } \\
\text { (\%) }\end{array}$ \\
\hline Crude extract & 500 & 89.8 & 59 & 1 & 100 \\
\hline Cetonic precipate & 465 & 30 & 125 & 2.11 & 93 \\
\hline DEAE-Sephadex & 136 & 0.95 & 242 & 4.09 & 27 \\
\hline Superdex 75 & 256 & 1.16 & 352 & 5.94 & 51 \\
\hline
\end{tabular}

reflected in the enzyme recovery and yield and in the obtaining of a single active peak. For that, the partially purified enzyme was applied in a DEAE-Sephadex G-50 column, resulting of fractions eluted by $\mathrm{NaCl}(1 \mathrm{M})$. Figure 1 shows the arrows to comprise the pooled containing protein with enzymatic activity. The eluted protein fraction, correspondent to the peaks highlighted in the Figure 1, showed a 4.09fold purification (specific activity of $242.0 \mathrm{U} /$ $\mathrm{mL}$ ). Further, the active pooled peaks were concentrated, lyophilized, resuspended, and then submitted through a Superdex G-75 column, what resulted in a varied pattern of protein, however with single protease fraction. That fraction was selected and re-submitted into the same Superdex G-75 column, obtaining a single active peak with 51\% protease recovery and 5.94fold purification (specific activity of $352 \mathrm{U} / \mathrm{mL}$ ). The isolated peak obtained in the chromatogram 2 (Figure 2) was correlated to a band of $\sim 47.0 \mathrm{kDa}$ in the electrophoresis, showing a homogenous enzyme fraction under non-reducing conditions (Figure 3). The molecular mass of the enzyme purified from Gel filtration had the estimated mass compared with SDS-PAGE.

\section{Effects of inhibitors and metals on the protease activity}

Figure 4 shows the influence of metal ions on the purified protease activity. Among the metal ions, the presence of $\mathrm{Cu}^{+2}$ and $\mathrm{Zn}^{+2}$ provided the lowest residual protease activity, with 43.5\% (53 $\mathrm{U} / \mathrm{mL}$ ) and $47.3 \%(58 \mathrm{U} / \mathrm{mL})$, respectively. The ion $\mathrm{Ca}^{+2}$, in contrast, increased by $30 \%$ the residual protease activity, acting as an inductor of activity. According to Purushothaman et al. (2019), the catalytic activity of many enzymes depends on smaller molecules called non-protein cofactors, which can be grouped into two classes: metal ions and the coenzymes. About the activity under presence of metal ions, $\mathrm{Zn}^{+2}$ promoted a slight increase in activity, different from the data presented in this paper.

Among the inhibitors, PMSF and EDTA presented the highest levels of inhibition, decreasing the residual activity to $30.4 \%$ and $45.7 \%$ of their initial value, respectively (Table II). An inhibition of $70 \%$ of the protease activity by PMSF indicates that the enzyme is a serine protease. Negi \& Banerjee (2009) purified a protease from Aspergillus awamori and found no inhibition using PMSF and EDTA. Asker et al. (2013) have discussed the inhibition for both PMSF and EDTA, where the complete inhibition of protease by PMSF is highly indicative of the presence of serine residue in active site, although the inhibition by EDTA might lead a misinterpretation of the inhibition causes, since a large number of enzyme require calcium for their activity, and EDTA as chelator could hinder the calcium effect. 


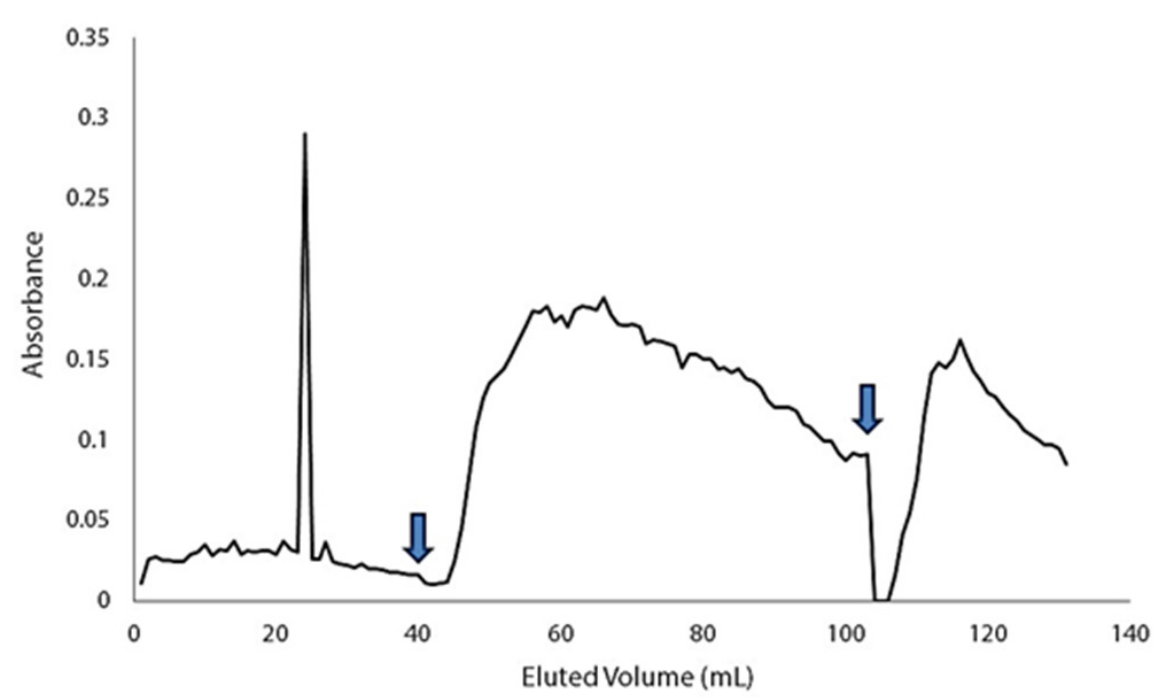

a)

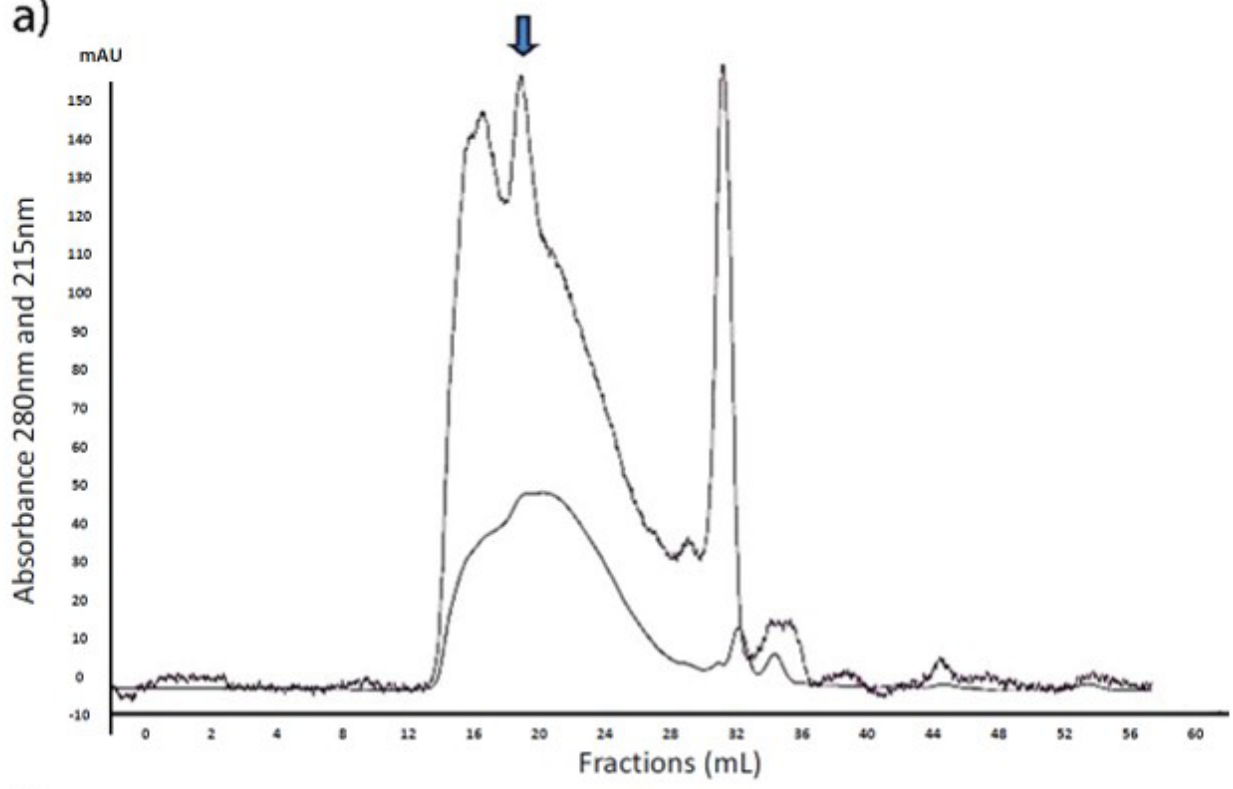

b) mau

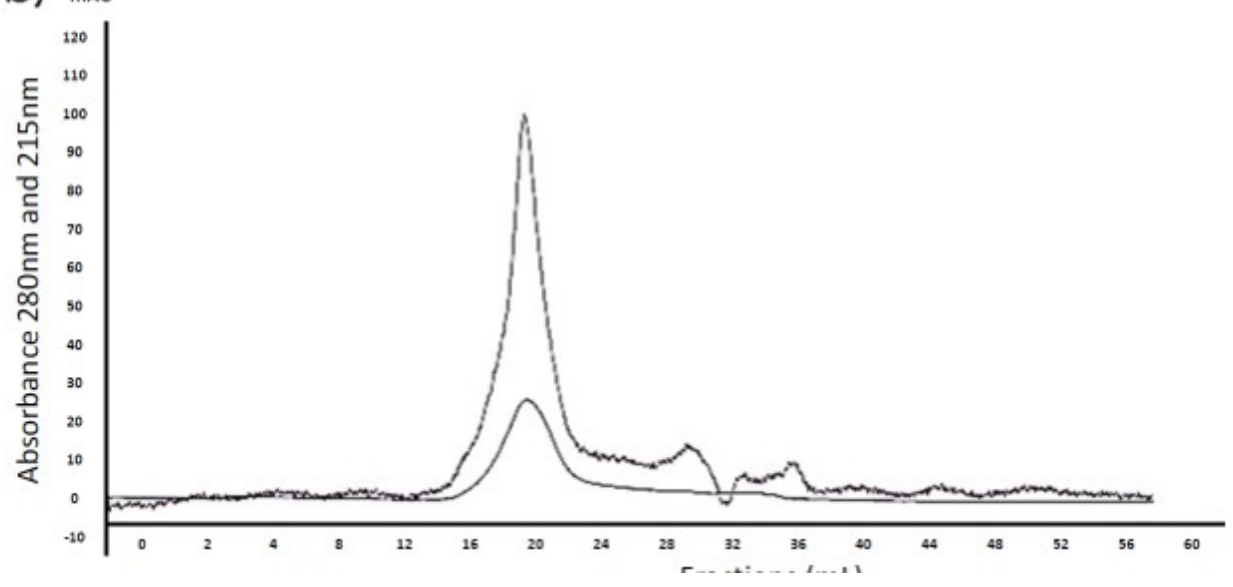

Figure 1. Elution profile from DEAE-Sephadex anion exchange chromatography of a sample obtained from acetonic precipitation of liquid metabolic from Aspergillus sydowii URM5774 extract after solid state fermentation. The marks show the fractions containing the protease activity. The content of the protein was expressed as the absorbance at $280 \mathrm{~nm}$.
Figure 2. Elution profile from Superdex 75 FPLC system. a) First run: Chromatogram containing varied peaks of protein with the protease peak pointed out. b) Second run: Isolated fraction containing the peak of protease found in a). The content of the protein was expressed as the absorbance at 215 $\mathrm{nm}$. 


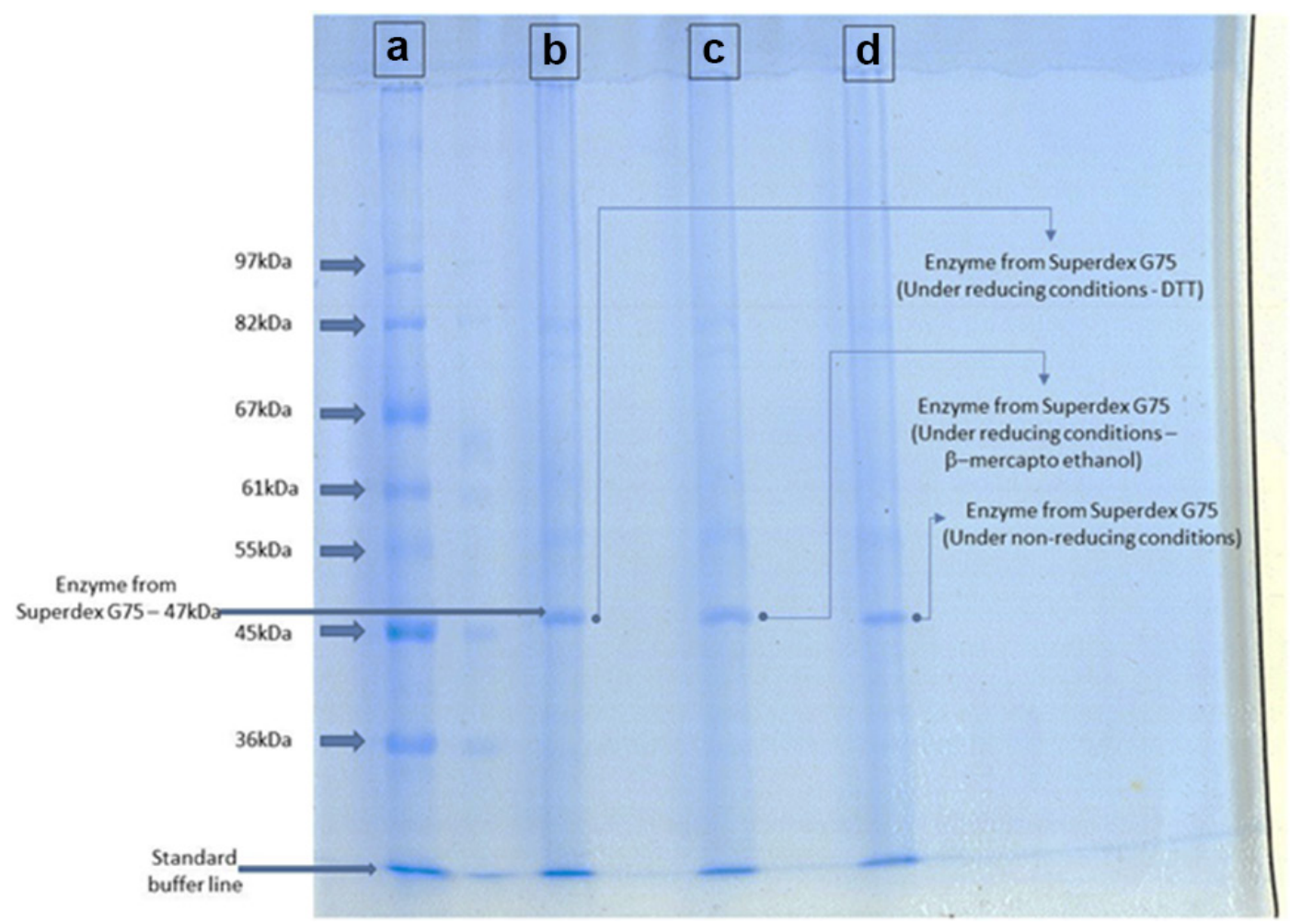

Figure 3. SDS-PAGE (10\%) image of enzyme produced and purified from Aspergillus sydowii by FPLC system. (a) Molecular markers; (b) Enzyme purified under reducing conditions in presence of DTT; (c) Enzyme purified under reducing conditions in presence of $b$-mercapto ethanol; (d) Enzyme purified under non- reducing conditions. The standard proteins $(x)$ used to calculate the linear regression: ribonuclease $A(13.7 \mathrm{kDa})$, carbonic anhydrase (29kDa), ovalbumin $(43 \mathrm{kDa})$, conalbumin $(75 \mathrm{kDa})$, aldolase $(158 \mathrm{kDa})$, ferritin $(440 \mathrm{kDa})$, and thyroglobulin $(669 \mathrm{kDa})$. The molecular mass of purified enzyme was calculated from the standard curve.

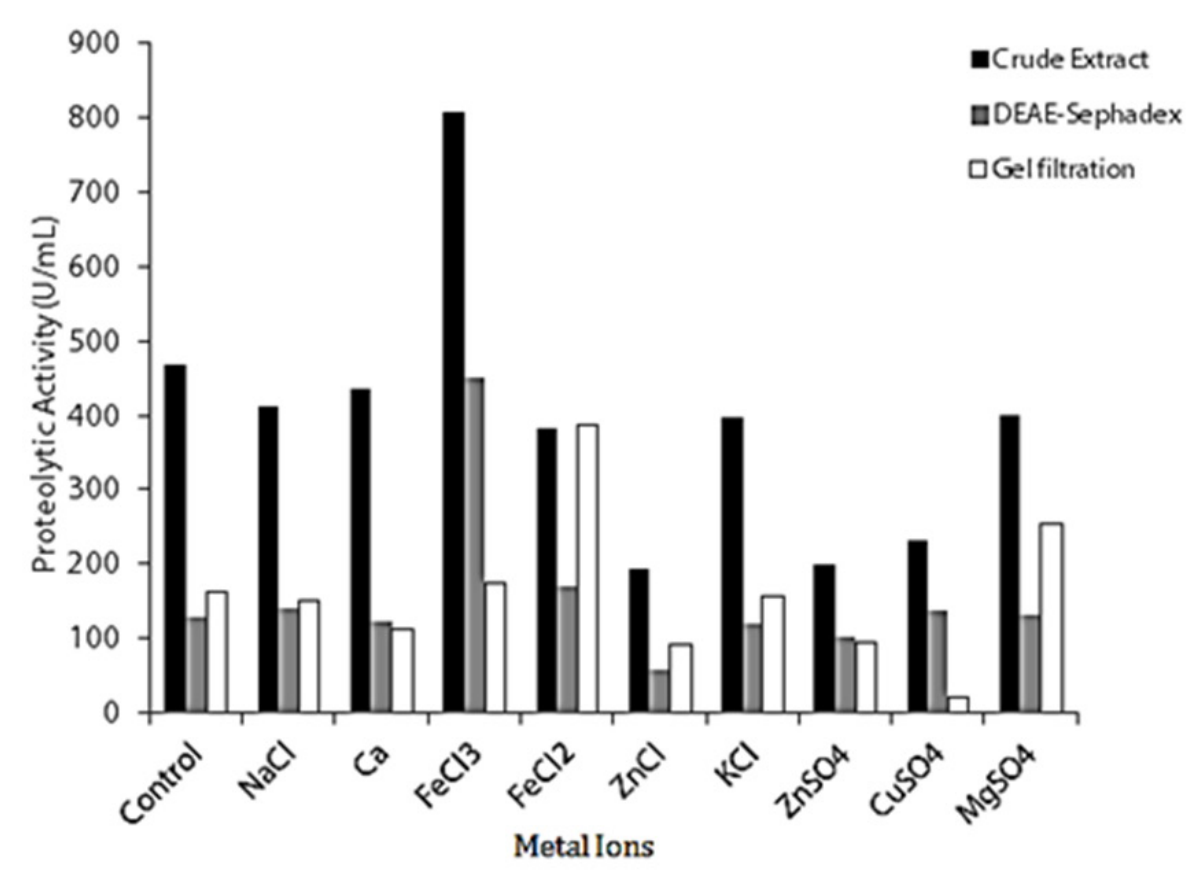

Figure 4. Effect of metal ions and inhibitors on the protease activity. Protease assays were carried out using purified protease $(0.75 \mu \mathrm{g})$. 


\section{Effects of temperature and $\mathrm{pH}$, and inhibitors on the protease activity and stability}

In Figure 5, we observed that the temperature for the maximum protease activity was $45^{\circ} \mathrm{C}$, however the activity was abruptly decreased in the interval of $5^{\circ} \mathrm{C}$, achieving a decrease of up $68 \%$. The thermal stability is an essential factor for application of proteases. The protein herein studied was active and thermostable from $25^{\circ} \mathrm{C}$ to $55^{\circ} \mathrm{C}$ (low activity levels were kept until $60^{\circ} \mathrm{C}$ ).

In work carried out by Singh (2017) with Aspergillus oryzae, the protease activity remained stable up to $50^{\circ} \mathrm{C}$, when there was a sharp decline of the activity, possibly due to denaturation of the protease. These data corroborate the data presented in this paper.

Regarding the optimal temperature was observed to $40^{\circ} \mathrm{C}$ showed a proteolytic activity of $478 \mathrm{U} / \mathrm{mL}$ as shown in Figure 5 . Similar results were found in fungal protease derived from fermentation of Aspergillus flavipes with the optimum temperature being $50^{\circ} \mathrm{C}$ Novelli et al. (2016), and Myceliophthora sp. with optimum temperature was between 40 to $45^{\circ} \mathrm{C}$ (Zanphorlin et al. 2011).

Previous studies indicated the improved thermostability of proteins with increased levels
Table II. Effect of specific protease inhibitors on catalytic activity of purified enzyme.

\begin{tabular}{|c|c|}
\hline Type of inhibitor & $\begin{array}{c}\text { Percentual of residual } \\
\text { activity (\%) }\end{array}$ \\
\hline Enzyme control & 100 \\
\hline Pepstatin A & 100 \\
\hline Iodoacetic acid & 44 \\
\hline EDTA & 10 \\
\hline PMSF & 0 \\
\hline Triton-X100 & 28 \\
\hline
\end{tabular}

of some glycosylation (Lim et al. 2019). The protease purified in this work and confirmed by electrophoresis not shown glycosylation by Schiff technique (data not shown). Among the tested protease, the remaining activity of purified protease increased slightly at temperatures above $60^{\circ} \mathrm{C}$ but the activity declined to $10 \%$ at $100^{\circ} \mathrm{C}$.

Figure 6 shows that the optimum pH for the purified enzyme. The enzyme maintained considerable activity during $1 \mathrm{~h}$ of incubation in $\mathrm{pH}$ between 5.0 and 9.0, although under acidic conditions the activity was constantly

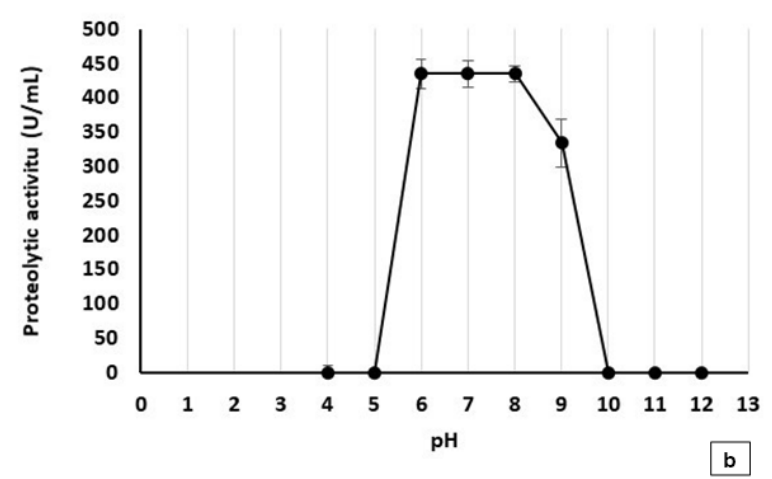

Figure 5. Effect of the pH on purified protease activity obtained from Aspergillus sydowii URM5774. Optimum pH (a) and $\mathrm{pH}$ stability (b) of the purified enzyme. Protease assays were carried out using purified protease $(0.75 \mu \mathrm{g})$. Error bars represent the standard deviation of triplicate measurements. 
decreased. The $\mathrm{pH} 8$ provided the best activity level for purified enzyme, what evidences the alkaline character of the enzyme, although next to neutral $\mathrm{pH}$, since after $\mathrm{pH} 9$ the activity of the enzyme decreased abruptly. This makes the protease suitable to applications in neutralalkaline environments. Alkaliphiles have made a great impact in industrial applications. Biological detergents contain alkaline enzymes, such as alkaline cellulases and/or alkaline proteases, that have been produced from alkaliphiles (Derombise et al. 2009). The current proportion of total world enzyme production destined for the laundry detergent market exceeds $60 \%$, for example. Besides, neutralalkaline environments are important to polymer degradation and Alkaline environments benefit microbial K-strategists to efficiently utilize protein substrate and promote valorization of protein waste into short-chain fatty acids (Wang et al. 2020).

According to studies by Markaryan et al. (1994) using Aspergillus fumigatus was shown a pH optimum between 7.5 and 8 and Souza et al. (2017) A. foetidus with the optimum pH was between 8-9 but keeping a high rate of activity between $\mathrm{pH}$ 5-9 and $A$. flavipes the optimum $\mathrm{pH}$ was 8 having a good performance in the enzymatic activity in the $\mathrm{pH}$ range $7-9$. Similar results to those found in this research. This broad $\mathrm{pH}$ range of proteases produced must be due to the genus Aspergillus ability to adapt to a wide $\mathrm{pH}$ range having as preferred $\mathrm{pH}$ acid being one acidophilus. This genus could modify the $\mathrm{pH}$ of the medium because of the ability to acidify the medium according to Straat et al. (2014).

In Table II, the purified protease was unaltered by all inhibitors, except Phenylmethyl sulfonyl fluoride (PMSF) is a well-known inhibitor of serine-protease (Table II). The purified protease from Aspergillus sydowii was strongly inhibited by PMSF, suggesting that the protease exhibits the serine amino acid near the active site, indicating to be a serine-collagenase. Effect of inhibition by PMSF has also been reported in serine-proteases. The moderate stability of protease in the presence of chelating agents like EDTA is a requirement for any detergent enzyme since EDTA is used in detergent formulation as a water softener.

The ability of the enzyme produced by $A$. sydowii to hydrolyze azocasein was accessed using the optimum parameters $45^{\circ} \mathrm{C}$ and $\mathrm{pH}$ 8.0 (Figure 7). Our findings agree with the report on fungi like Aspergillus niger, Mucor disperses NRRL 3103 and A. elegans NRRL 3104 which were studied for their substrate specificity. Hydrolysis of azocasein has been the source of the fermented compounds. Degradation of proteins like azocasein increases the free amino acid content during fermentation processing, particularly for glutamic acid and alanine, which are the most important substances for producing the characteristic taste and flavour for example in meats.

\section{CONCLUSION}

The enzyme from Aspergillus sydowii produced by solid state fermentation using coffee residues was herein purified and proved to have a biotechnological potential for use in the detergent industry and leather softening as well as a possible solution to the impact environment caused by the coffee grounds of disposal. The findings were presented can be useful for the enzyme industry since they represent a way to manage the waste of raw converting into a viable economic product. 

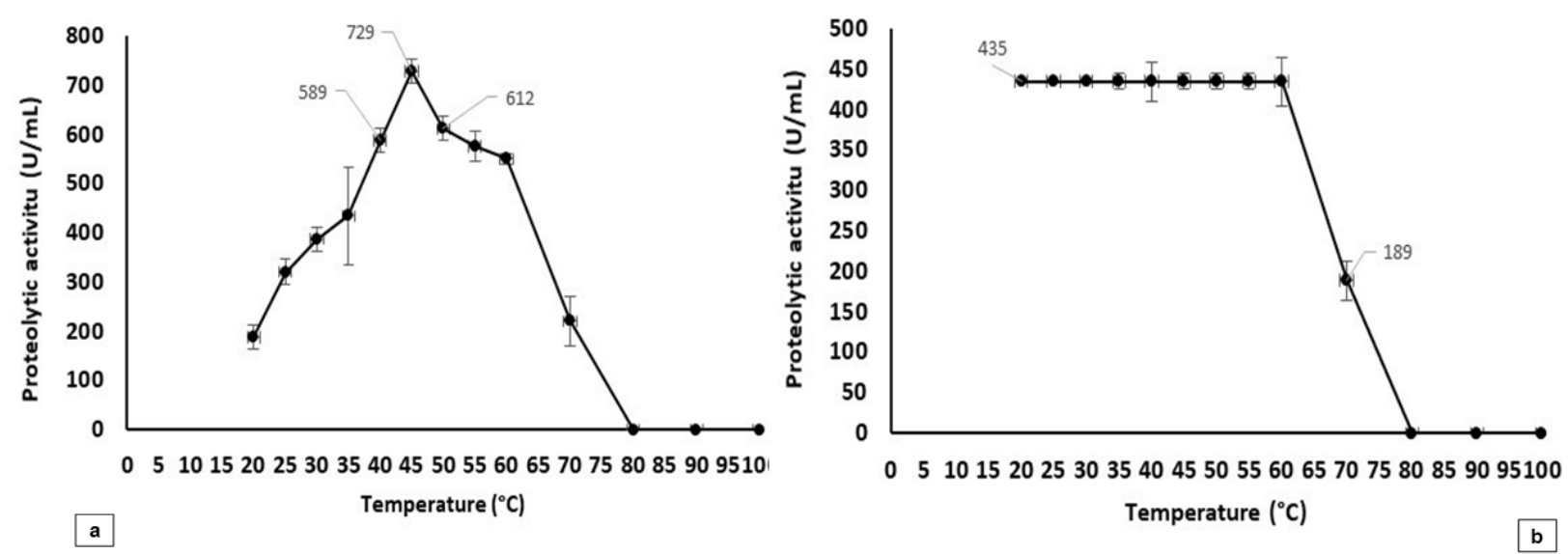

Figure 6. Optimum temperature (a) and temperature stability (b) assays to evaluate the activity of the purified enzyme obtained from Aspergillus sydowii URM5774. Protease assays were carried out using purified protease $(0.75 \mu \mathrm{g})$. Error bars represent the standard deviation of triplicate measurements.
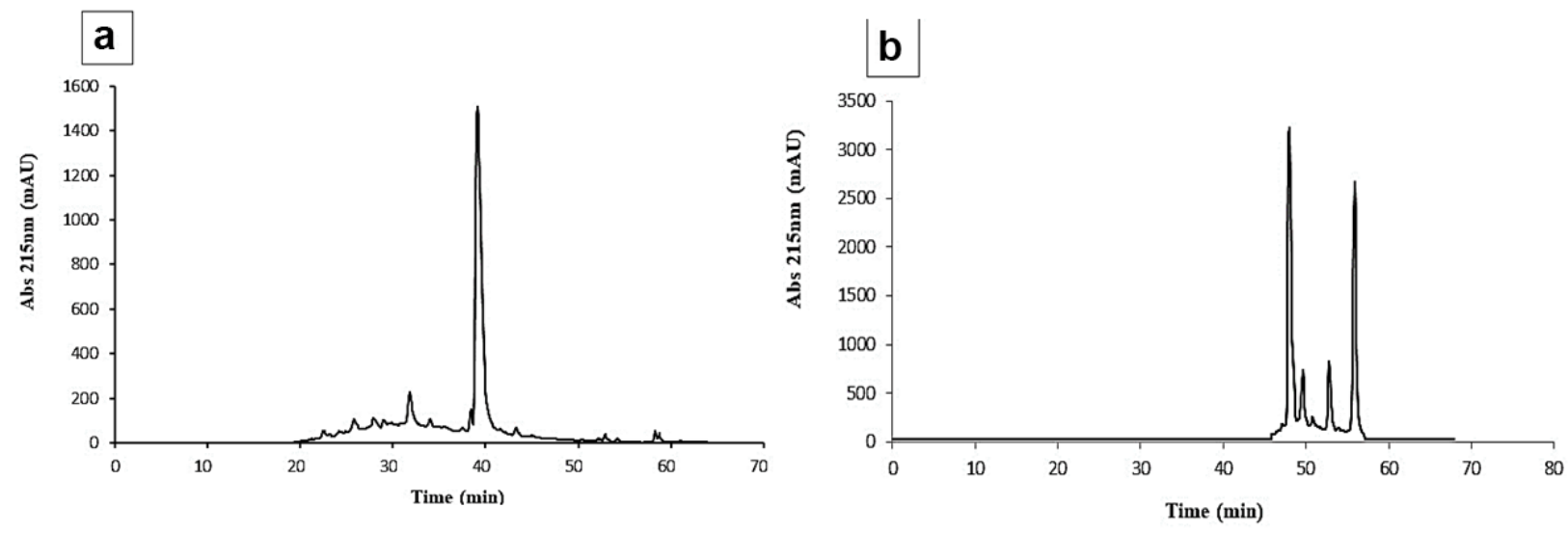

Figure 7. HPLC chromatogram profile of azocasein degradation process using a protease purified from $A$. sydowii. (a) HPLC profile of Azocasein purchased from Sigma; (b) HPLC profile of Azocasein hydrolysis using a protease purified through the optimum parameters.

\section{Acknowledgments}

The authors thank FACEPE (Fundação de Amparo à Ciência e Tecnologia do Estado de Pernambuco) for funding the present study.

\section{REFERENCES}

ALBUQUERQUE KKSA, ALBUQUERQUE WWC, COSTA RMPB, BATISTA JMS, MARQUES DAV, BEZERRA RP, HERCULANO PN \& PORTO ALF. 2020. Biotechnological potential of a novel tannase-acyl hydrolase from Aspergillus sydowii using waste coir residue: Aqueous two-phase system and chromatographic techniques. Biocatal Agric Biotechnol 23: 101453.

ASKER MMS, MAHMOUD MG, EL SHEBWY K \& ABD EL AZIZ MS. 2013. Purification and characterization of two thermostable protease fractions from Bacillus megaterium. J Genet Eng Biotechnol 11(2): 103-109.

CASTRO RJS, NISHIDE TG \& SATO HH. 2014. Production and biochemical properties of proteases secreted by Aspergillus niger under solid state fermentation in response to different agroindustrial substrates. Biocatal Agric Biotechnol 3(4): 236-245.

DEROMBISE G, VOUYOVITCH L \& DAVIES P. 2009. Degradation of Technora aramid fibres in alkaline and neutral environments. Polym Degrad Stab 94: 615-1620. 
GINTHER CL. 1979. Sporulation and the Production of Serine Protease and Cephamycin C by Streptomyces lactamdurans. Antimicrob Agents Chemother 15(4): 522-526.

LAEMMLI UK. 1970. Cleavage of Structural Proteins during the Assembly of the Head of Bacteriophage T4. Nature 227(5259): 680-685.

LIM L, SENBA H, KIMURA Y, YOKOTA S, DOI M, YOSHIDA KI \& TAKENAKA S. 2019. Influences of $\mathrm{N}$-linked glycosylation on the biochemical properties of aspartic protease from Aspergillus glaucus MA0196. Process Biochem 79: 74-80.

MANSOR A, RAMLI MS, ABDUL RASHID NY, SAMAD N, LANI MN, SYARIFUDDIN SA \& SIVA MANIKAM RV. 2019. Evaluation of selected of agri-industrial residues as potential substrates for enhanced tannase production via solidstate fermentation. Biocatal Agric Biotechnol 20: 101216.

MARKARYAN A, MOROZOVA I, YU H \& KOLATTUKUDY PE. 1994. Purification and characterization of an elastinolytic metalloprotease from Aspergillus fumigatus and immunoelectron microscopic evidence of secretion of this enzyme by the fungus invading the murine lung. Infect Immun 62(6): 2149-2157.

NASCIMENTO TP, SALES AE, PORTO TS, COSTA RMPB, BREYDO L, UVERSKY VN, PORTO ALF \& CONVERTI A. 2017. Purification, biochemical, and structural characterization of a novel fibrinolytic enzyme from Mucor subtilissimus UCP 1262. Bioproc Biosystems Eng 40(8): 1209-1219.

NEGI S \& BANERJEE R. 2009. Characterization of amylase and protease produced by Aspergillus awamori in a single bioreactor. Int Food Res J 42(4): 443-448.

NOVELLI PK, BARROS MM \& FLEURI LF. 2016. Novel inexpensive fungi proteases: Production by solid state fermentation and characterization. Food Chem 198: 119-124.

PURUSHOTHAMAN K, BHAT SK, SINGH SA, MARATHE GK \& APPU RAO ARG. 2019. Aspartic protease from Aspergillus niger: Molecular characterization and interaction with pepstatin A. Int J Biol Macromol 139: 199-212.

SETHI BK, JANA A, NANDA PK, DAS MOHAPATRA PK \& SAHOO SL. 2016. Thermostable acidic protease production in Aspergillus terreus NCFT 4269.10 using chickling vetch peels. J Taibah Univ Sci 10(4): 571-583.

SILVA OS, DE ALMEIDA EM, DE MELO AHF \& PORTO TS. 2018. Purification and characterization of a novel extracellular serine-protease with collagenolytic activity from Aspergillus tamarii URM4634. Int J Biol Macromol 117: 1081-1088.

SINGH SB. 2017. Purification and characterization of a protease-resistant phytase of Aspergillus oryzae SBS50 whose properties make it exceptionally useful as a feed supplement. Int J Biol Macromol 103: 458-466.

SMITH PK, KROHN RI, HERMANSON GT, MALLIA AK, GARTNER FH, PROVENZANO MD, FUJIMOTO EK, GOEKE NM, OLSON BJ \& KLENK DC. 1985. Measurement of protein using bicinchoninic acid. Anal Biochem 150(1): 76-85.

SOUZA PM, WERNECK G, ALIAKBARIAN B, SIQUEIRA F \& JUNIOR AP. 2017. Production, purification and characterization of an aspartic protease from Aspergillus foetidus. Food Chem Toxicol 109: 1103-1110.

SOUZA PM, BITTENCOURT MLA, CAPRARA CC, DE FREITAS M, ALMEIDA RPC, SILVEIRA D, FONSECA YM, FERREIRA FILHO EX, PESSOA JUNIOR A \& MAGALHÃES PO. 2015. A biotechnology perspective of fungal proteases. Braz J Microbiol 46(2): 337-346.

TANG J, CHEN T, HU Q, LEI D, SUN Q, ZHANG S, ZENG C \& ZHANG Q. 2020. Improved protease activity of Pixian broad bean paste with co-cultivation of Aspergillus oryzae QM-6 and Aspergillus niger QH-3. Electron J Biotechnol: doi. org/10.1016/j.ejbt.2020.01.001.

VISHWANATHA KS, APPU RAO AG \& SINGH SA. 2009. Production and characterization of a milk-clotting enzyme from Aspergillus oryzae MTCC 5341. Appl Microbiol Biotechnol 85(6): 1849-1859.

WANG XU, ZHANG YA, LI Y \& BUTLER D. 2020. Alkaline environments benefit microbial K-strategists to efficiently utilize protein substrate and promote valorization of protein waste into short-chain fatty acids. Chem Eng Sci 404: 127147.

ZANPHORLIN LM, CABRAL H, ARANTES E, ASSIS D, JULIANO L, JULIANO MA, DA-SILVA R, GOMES E \& BONILLA-RODRIGUEZ GO. 2011. Purification and characterization of a new alkaline serine protease from the thermophilic fungus Myceliophthora sp. Process Biochem 46(11): 2137-2143.

ZENEBON O ET AL. 2008. Métodos físico-químicos para análise de alimentos. 4. ed. Instituto Adolfo Lutz - IAL, São Paulo.

\section{How to cite}

ROCHA FTB, BRANDÃO-COSTA RMP, NEVES AGD, CARDOSO KBB, NASCIMENTO TP, ALBUQUERQUE WWC \& PORTO ALF. 2021. Purification and characterization of a protease from Aspergillus sydowii URM5774: Coffee ground residue for protease production by solid state fermentation. An Acad Bras Cienc 93: e20200867. DOI 10.1590/00013765202120200867 .

Manuscript received on June 12, 2020; accepted for publication on January 06, 2021 


\title{
FELYPE T.B. ROCHA ${ }^{1}$
}

https://orcid.org/0000-0002-7323-1243

ROMERO M.P. BRANDÃO-COSTA ${ }^{2,1}$

https://orcid.org/0000-0001-7045-2975

\section{ANNA GABRIELLY D. NEVES ${ }^{1}$}

https://orcid.org/0000-0002-2089-5302

KETHYLEN B.B. CARDOSO ${ }^{1}$

https://orcid.org/0000-0003-0317-0307

THIAGO P. NASCIMENTO 1

https://orcid.org/0000-0003-3480-6734

WENDELL W.C. ALBUQUERQUE ${ }^{3}$

https://orcid.org/0000-0001-7658-491X

\begin{abstract}
ANA LÚCIA F. PORTO ${ }^{1}$
https://orcid.org/0000-0001-5561-5158

'Universidade Federal Rural de Pernambuco/UFRPE, Laboratório de Tecnologia de Bioativos, Rua Dom Manuel de Medeiros, s/n, Dois Irmãos, 52171-900 Recife, PE, Brazil ${ }^{2}$ Universidade de Pernambuco, Laboratório de Avanços em Biotecnologia de Proteínas / LABIOPROT, Rua Arnóbio Marquês, 310, Santo Amaro, 50100-130 Recife, PE, Brazil ${ }^{3}$ Institute of Food Chemistry and Food Biotechnology, Justus Liebig University Giessen, HeinrichBuff-Ring 17, Giessen, 30392 Germany
\end{abstract}

Correspondence to: Romero Marcos Pedrosa Brandão-Costa

E-mail:romero.brandao@upe.br

\section{Author contributions}

All authors contributed to the development of the manuscript: Felype T.B. Rocha and Romero M.P.B. Costa isolated the microorganism Aspergillus sydowii from the coffee grounds and identified by the URM Culture Collection of the Federal University of Pernambuco. Besides, they prepared the solidstate fermentation technique. Anna Gabrielly D. Neves did the enzyme extraction and determined the proteolytic activity. Kethylen B.B. Cardoso and Thiago P. Nascimento did partial purification process of the enzyme after extraction procedure. Follow, the sample was purified by DEAE-Sephadex Chromatography. Wendell W.C. Albuquerque used Gel Filtration Chromatography under AKTA AVANT equipment to purify the enzyme. Ana Lúcia F. Porto improved the research with statistical analyses. The authors declare that they have no conflict of interest.

\section{(cc) BY}

